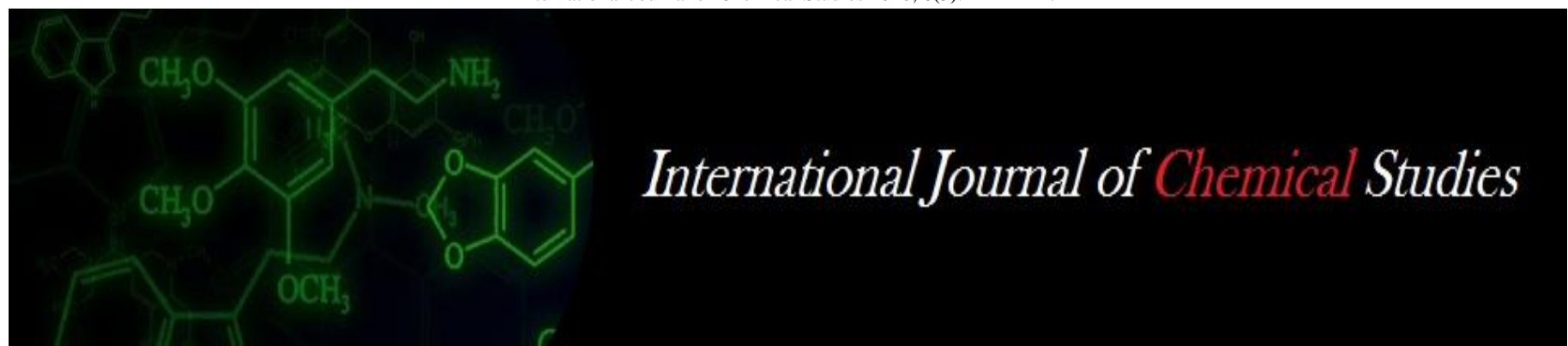

P-ISSN: 2349-8528

E-ISSN: 2321-4902

www.chemijournal.com

IJCS 2020; 8(5): 2124-2127

(C) 2020 IJCS

Received: 20-07-2020

Accepted: 25-08-2020

Amrit Kumar Jha

Krishi Vigyan Kendra (Birsa

Agricultural University),

Sahibganj, Jharkhand, India

Kaushik Chatterjee

Krishi Vigyan Kendra (Birsa

Agricultural University),

Sahibganj, Jharkhand, India

Birendra Kumar Mehta

Krishi Vigyan Kendra (Birsa

Agricultural University)

Sahibganj, Jharkhand, India

\section{Maya Kumari}

Krishi Vigyan Kendra (Birsa

Agricultural University),

Sahibganj, Jharkhand, India

Corresponding Author:

Amrit Kumar Jha

Krishi Vigyan Kendra (Birsa

Agricultural University)

Sahibganj, Jharkhand, India

\section{Effect of technological interventions of cluster frontline demonstrations (CFLDs) on Productivity and profitability of black gram (Vinga mungo L.) in Sahibganj district of Jharkhand}

\author{
Amrit Kumar Jha, Kaushik Chatterjee, Birendra Kumar Mehta and \\ Maya Kumari
}

DOI: https://doi.org/10.22271/chemi.2020.v8.i5ac.10620

\begin{abstract}
The present study was carried out to evaluate the performance of technological interventions like improved variety, line sowing, seed treatments with fungicide and biofertilizer, balanced nutrition and weed management on productivity and profitability of black gram. Black gam is an important kharif pulse crop in Sahibganj district of Jharkhand covering over 5218 ha with average productivity of $6.5 \mathrm{q} / \mathrm{ha}$ which is well below the state average $(9.25 \mathrm{q} / \mathrm{ha})$ and national average $(9.7 \mathrm{q} / \mathrm{ha})$. Unavailability of improved variety as well as non-adoption of improved cultivation practices in the district is one of the possible reasons for lower average productivity of black gram in the district. To enhance productivity of black gram through improved variety and cultivation practices cluster frontline demonstrations (CFLDs) were conducted during kharif season from 2016-17 to 2019-20. Performance of black gram variety PU 31 in 160 locations along with improved cultivation practices like line sowing, treatment of seed with fungicide and biofertilizer, balanced nutrition and weed management were evaluated in Barharwa and Rajmahal blocks of the district. It was observed that the yield of black gram in CFLD under rainfed conditions ranged from 9.48 to $9.60 \mathrm{q} / \mathrm{ha}$ whereas in FP it ranged between 6.35 to $6.53 \mathrm{q} / \mathrm{ha}$. The per cent increase in yield with Improved Practices (IP) over FP was recorded in the range of 46.15 to 49.2 . The extension gap and technological index were ranging between 3.0 to $3.13 \mathrm{q} / \mathrm{ha}$ and 26.15 to 27.07 per cent, respectively. The trend of technology gap reflected the farmer's cooperation in carrying out demonstrations with encouraging results in subsequent years. The benefit cost ratio was 2.03 to 2.16 under demonstration, while it was 1.54 to 1.76 under farmer's practice. Therefore, the results clearly indicate that the use of improved variety and package of practice with scientific intervention under cluster frontline demonstration programme contribute to increase the productivity and profitability.
\end{abstract}

Keywords: Extension gap, technology transfer, yield, cluster frontline demonstrations, technology index

\section{Introduction}

Black gram being native to India is one of the important pulse crops grown throughout the country. It is very widely used in Indian cuisine and well known by the name urad dal in hindi consumed mainly in form of 'dal' (whole or split, husked and unhusked). It is also used as nutritive fodder for milch animals and as green manuring crop. High value of protein, potassium, calcium, iron, niacin, thiamine, riboflavin in black gram makes it an excellent complement to rice in terms of balanced human nutrition. In Jharkhand black gram occupies a major position in terms of area, production and productivity among the pulses. According to the annual report, 2017-18, GOI, Ministry of Agriculture \& Farmer's Welfare (Department of Agriculture, Cooperation \& Farmers Welfare) black gram is cultivated in 1.48 lakh hectare with a production of 1.36 lakh tones which constitute $1.48 \%$ of national area and $1.36 \%$ of production. Black gram is also an important pulse crop of Sahibganj district and occupies an area of 5,218 ha. Kharif black gram is mostly sown in July-August and harvested OctoberNovember. The PU 31 is a bold seeded Yellow Mosaic Virus (YMV) tolerant variety with crop duration of 75-85 days depending upon the environmental conditions. Increasing population, consumer awareness and affordability of middle/lower middle and other category citizens up to some degree, the demand of pulse has increased overtime. Over a period of time, a number of improved black gram varieties and production technologies have been 
developed, but the full potential of the varieties as well as technologies could not be exploited due to low rate of adoption and low yield. Thus, factor limiting to productivity cannot be overlooked. Research and extension programme need to be diverted to produce value additive pulse. It may emphasize on quality attributes, adoption and popularization of new agro-technologies, evolving better varieties for stress conditions and improving present yield potential with an aim to raise production through transfer of farm technology.

Cluster front line demonstration (CFLD) is a novel approach to provide a direct interface between researcher and farmer for the transfer of technologies developed by them and to get direct feedback from farming community. To meet the growing demand for food grains, National Development Council (NDC) in its $53^{\text {rd }}$ meeting adopted a resolution to enhance the production of rice, wheat and pulse by 10,8 and 2 million tons respectively by 2011 with an outlay of Rs. 4,882 corers under National Policy for Farmers in the Eleventh Five Year Plan. The proposed centrally sponsored scheme 'National Food Security Mission (NFSM)' is to operationalize the resolution of NDC and enhance the production of food grains (Annonymous, 2011) ${ }^{[1]}$. The concept of Cluster Frontline Demonstration was put forth under this mission. The scheme implemented in a mission mode through a farmer centric approach. The basic strategy of the mission is to promote and extend improved technologies, i.e., seed, micronutrient, soil amendments, integrated pest management, farm machinery and implements, irrigation devices along with capacity building of farmers. The project was implemented by Krishi Vigyan Kendra, Sahibganj with main objective to boost the production and productivity of pulse through CFLD with latest and specific technologies.

\section{Materials and Method}

The study was carried out during Kharif season from 2016-17 to 2019-20 (4 consecutive years) by the KVK Sahibganj, Jharkhand. The villages covered under CFLDs were Chapujan (Block - Barharwa) in 2016-17, Bhimpara (Barharwa) in 2017-18, Lalbandh (Block - Rajmahal) in 2018-19 and Madhuapara (Block - Barharwa) in 2019-20 of Sahibganj district of Jharkhand. Number of locations (beneficiaries) during 2016-17,2017-18, 2018-19 and 2019-20 were 47, 34, 54 and 25, respectively totalling 160 . Beneficiaries (farmers/ farmwomen) were identified through their participation and feedback received during the preliminary survey, awareness programmes and interactive meetings. Farmers were trained to follow the package and practices for black gram cultivation as recommended by the Birsa Agricultural University and critical inputs for the technologies like seeds, fungicides, biofertilizers were distributed to the farmers however balanced plant nutrients on the basis of soil test value were applied by the farmers from their own resources. Detail of technological interventions are presented in table 1. Regular field visit, monitoring and need based advisories were provided by the scientists of KVK. All 160 demonstration in 50-hectare area were conducted by the active participation of the farmers with an objective to demonstrate the improved technologies of black gram production potential in different villages. In case of local check, the traditional practices were followed by using existing variety. In demonstration plots, use of quality seeds of improved variety (PU 31), line sowing and timely weeding, need based pesticide as well as balanced fertilizer were emphasized. In general, the soil of the experimental plots were sandy loam in texture, acidic in soil reaction ( $\mathrm{pH} 5.8$ to 6.2 ), low to medium in organic carbon
( 0.42 to $0.61 \%$ ), medium status in available nitrogen (310 to $360 \mathrm{~kg} / \mathrm{ha}$ ), low to medium in available phosphorus (8.4 to $12.6 \mathrm{~kg} / \mathrm{ha}$ ) and also low to medium in available potassium (108 to $131 \mathrm{~kg} / \mathrm{ha})$. The farmers under the programme were facilitated by KVK scientists in performing field operations like sowing, spraying, weeding, harvesting etc. Finally, field day was conducted involving demonstration holding farmers, other farmers in the village, scientist from KVK, officials from Department of Agriculture, local extension functionaries to demonstrate the superiority of technology. The basic information was recorded from the demonstration and control plots and analyzed for comparative performance of the cluster frontline demonstrations (CFLDs) and farmer's practice. The yield data were collected both from the demonstration and farmers practice by random crop cutting method and analyzed by using simple statistical tools. The technology gap and technological index (Yadav et al., 2004) ${ }^{[2]}$ along with the benefit cost ratio (Samui et al., 2000) ${ }^{[3]}$ were calculated by using following formula as given below.

Extension Gap $=$ Demonstration Yield - Farmer'sPractice Yield

Technology Gap = Potential Yield - Demonstration Yield

Additional Return $=$ Demonstration Return - Farmer'sPractice Return

Technology Index $=\frac{\text { Potential Yield }- \text { Demonstration Yield }}{\text { Potential Yield }} \times 100$

Percent increase in yiels $=\frac{\text { Demonstration Yield }- \text { Farmer's Practice Yield }}{\text { Farmer'sPractice Yield }} \times 100$

\section{Results and Discussion}

Results of the Cluster Frontline Demonstrations conducted during 2016-17 to 2019-20 in different villages of Sahibganj revealed that the improved package and practices is more important with technological intervention for productivity and profitability of pulse. The cultivation practices comprised under CFLD viz use of improved variety, seed treatment, line sowing, balanced application of fertilizers, proper weed control and control of pest through insecticide at economic level evidentially proved superiority over farmer's practice (Table 2). Similar observations were reported by Singh et al. (2011). It was found that the average grain yield of black gram under cluster frontline demonstrations were ranged from $9.48 \mathrm{q}$ to $9.60 \mathrm{q}$ ha- 1 as compared to 6.35 to $6.53 \mathrm{q}$ ha- 1 in case of Farmer's Practice during 2016-17 to 2019-20. As far as per cent increase in demonstration yield over yield obtained under Farmers Practice is concern, an average of 47.52 per cent increase was found during the four years of demonstrations. Data presented in table 2 also indicates that the yield of black gram did not fluctuate significantly over the years in demonstration plots. Similar yield enhancement in different crops in cluster frontline demonstrations were documented by Hiremath et al., (2007) ${ }^{[4]}$ in Onion; Mishra et al., (2009) ${ }^{[5]}$ in Potato; Kumar et al., (2010) ${ }^{[6]}$ in Bajra; Dhaka et al., (2015) ${ }^{[7]}$ in Coriander. The results were also supported by Bairwa et al., (2013) ${ }^{[10]}$ in black gram and Hiremath and Nagaraju (2010) ${ }^{[12]}$ in Chilli crop. The increase in percent of yield was ranged from 46.15 to 49.2 during the four years of study. The results were in conformity with the findings of Katare et al., (2011) ${ }^{[8]}$, Meena et al., and Saikia et al. (2018) ${ }^{[15]}$. The extension gap ranging from 3 to $3.13 \mathrm{q} \mathrm{ha}^{-1}$ over the years of study emphasizes the need to educate the farmers through various means for adoption of improved agriculture practices to reverse the trend of wide extension 
gap. The trend of technology gap ranging between 3.4 to 3.52 $\mathrm{q} \mathrm{ha}^{-1}$ reflects the farmers cooperation in carrying out demonstrations with encouraging result in subsequent years. Similar findings were recorded by Katare et al., (2011) ${ }^{[8]}$ in oilseeds and Saikia et al., (2018) ${ }^{[15]}$ in black gram. The technology gap over the years of study may be attributed to dissimilarity in soil fertility status, rainfall distribution, pest infestation, weed intensity and change in locations of cluster frontline demonstration sites. However, the result observed is an evidence of the better performance in varied environmental condition over farmers practice. The technology index showed the feasibility of the evolved technology at the farmers field. The technology index ranging from 26.15 to 27.07 during the years of study exhibited a decreasing trend over the years with low fluctuation which may be attributed to the dissimilarity in weather condition, soil fertility status and non-availability of water in the crop. The lower the value of technology index the more is the feasibility of technology. Economic performance of black gram under cluster frontline demonstration presented in table 3 . Results of economic analysis parameter revealed that the black gram recorded higher total return of Rs.43,845/-, Rs.47,500/-, Rs.51,840/and Rs.51,460 per ha during 2016-17, 2017-18, 2018-19 and 2019-20, respectively under CFLDs as compared to Rs.29,369/-, Rs.32,500/-, Rs.35,262/- and Rs.34,830 per ha, respectively under farmers practice. Technologies demonstrated under CFLDs also had positive influence on net return and thereby benefit cost ratio (B:C ration) over farmers practice. The net return ranged from Rs.22,345/- to Rs.27,840/- per ha under recommended practice as compared to Rs.10,369/- to Rs.15,262/- per ha in farmer's practice. It was observed that the additional returns ranged from Rs.14,476/- to Rs.16,630/- per ha under recommended practices during the years. The higher benefit cost ratio was also recorded under recommended practices and the observed B:C ratio was 2.03, 2.11, 2.16 and 2.05 during 2016-17, 2017$18,2018-19$ and 2019-20, respectively as compared to 1.54 , $1.66,1.76$ and 1.65 , respectively under farmers practice. These results are in accordance with the findings of Gurumukhi and Mishra (2003) ${ }^{[11]}$, Singh et al., (2018) ${ }^{[13]}$ and Jayalakshmi et al., (2018) ${ }^{[14]}$.

Table 1: Difference between technological intervention and farmer's practices under CFLD on Black gram

\begin{tabular}{|c|c|c|c|}
\hline Particulars & Technological intervention in CFLD & Farmers practices & Gap \\
\hline Variety & PU 31 & Local/own seed & Full gap \\
\hline Seed rate & $20 \mathrm{~kg} / \mathrm{ha}$ & $25 \mathrm{~kg} / \mathrm{ha}$ & High seed rate \\
\hline $\begin{array}{l}\text { Sowing method/ } \\
\text { spacing }\end{array}$ & Line sowing $(30 \times 10 \mathrm{~cm})$ & $\begin{array}{l}\text { Broadcasting, uneven plant } \\
\text { population }\end{array}$ & Partial gap \\
\hline Time of sowing & June 15 to 15 July & July 15 to 15 August & Partial gap \\
\hline Seed Treatment & $\begin{array}{c}\text { Seed treatment was done with } 2.5 \mathrm{gm} \text { of Carbendazim, } 5 \mathrm{ml} \text { of Imidacloprid } \\
\text { per kg seed and with Rhizobium culture }\end{array}$ & No seed treatment & Full gap \\
\hline Fertilizer & $\begin{array}{l}\text { Balanced fertilizer application as per soil test values, } 44 \mathrm{~kg} \text { of urea in split } \\
\text { dose, } 250 \mathrm{~kg} \text { of ssp and } 34 \mathrm{~kg} \text { of mop as basal dose } / \mathrm{ha}\end{array}$ & $\begin{array}{l}\text { Imbalanced use of fertilizer } 50 \\
\mathrm{~kg} \text { urea as top dressing and 5o } \\
\mathrm{kg} \text { of DAP as basal dose/ha }\end{array}$ & Full gap \\
\hline $\begin{array}{c}\text { Weed } \\
\text { management }\end{array}$ & Application of Imazethapyr $10 \mathrm{SL} 75 \mathrm{~g}$ a.i. ha ${ }^{-1}$ at $15-20$ DAS & Manual weeding at 35-40 DAS & Full gap \\
\hline Plant Protection & $\begin{array}{c}\text { Neem oil @ } 5 \mathrm{ml} / \mathrm{ha} \text { and Chlorpyriphos } 2.5 \mathrm{ml} / \text { lit of water for control of } \\
\text { sucking pest. Practiced Integrated measures to control, Yellow vein mosaic } \\
\text { virus by growing maize/jowar as boarder crop, removal of weeds on bunds } \\
\text { and finally chemical measures }\end{array}$ & $\begin{array}{l}\text { Injudicious use of insecticides } \\
\text { and fungicides based on advice } \\
\text { of input dealers }\end{array}$ & $\begin{array}{c}\text { Partial gap } \\
\text { with high cost }\end{array}$ \\
\hline
\end{tabular}

Table 2: Grain yield and Gap analysis of cluster frontline demonstration on Black gram

\begin{tabular}{|c|c|c|c|c|c|c|c|c|}
\hline \multirow[t]{2}{*}{ Year } & \multirow{2}{*}{$\begin{array}{c}\text { Sample Area } \\
\text { (ha) }\end{array}$} & \multirow{2}{*}{$\begin{array}{l}\text { Sample No. of } \\
\text { farmers }\end{array}$} & \multicolumn{2}{|c|}{$\begin{array}{c}\text { Average yield } \\
\text { (Q/ha) }\end{array}$} & \multirow{2}{*}{$\begin{array}{l}\text { \% increase } \\
\text { over FP }\end{array}$} & \multirow{2}{*}{$\begin{array}{c}\text { Technology gap } \\
\text { (q/ha) }\end{array}$} & \multirow{2}{*}{$\begin{array}{l}\text { Extension gap } \\
\qquad(\mathrm{q} / \mathrm{ha})\end{array}$} & \multirow{2}{*}{$\begin{array}{c}\text { Technology Index (\%) } \\
\text { CFLD }\end{array}$} \\
\hline & & & Potentia & \begin{tabular}{l|l|} 
CFLD & FP \\
\end{tabular} & & & & \\
\hline $2016-17$ & 10 & 47 & $12-14$ & \begin{tabular}{l|l|}
9.48 & 6.35 \\
\end{tabular} & 49.2 & 3.52 & 3.13 & 27.07 \\
\hline $2017-18$ & 10 & 34 & $12-14$ & \begin{tabular}{|l|l|}
9.50 & 6.50 \\
\end{tabular} & 46.15 & 3.5 & 3.0 & 26.92 \\
\hline $2018-19$ & 20 & 54 & $12-14$ & \begin{tabular}{l|l|}
9.60 & 6.53 \\
\end{tabular} & 47.01 & 3.4 & 3.07 & 26.15 \\
\hline $2019-20$ & 10 & 25 & $12-14$ & \begin{tabular}{l|l|}
9.53 & 6.45 \\
\end{tabular} & 47.75 & 3.47 & 3.08 & 26.69 \\
\hline Average & - & - & 13 & \begin{tabular}{l|l|}
9.52 & 6.45 \\
\end{tabular} & 47.52 & 3.47 & 3.07 & 26.63 \\
\hline
\end{tabular}

Table 3: Economic analysis of the cluster frontline demonstrations on Black gram

\begin{tabular}{|c|c|c|c|c|c|c|c|c|c|}
\hline \multirow[b]{2}{*}{ Year } & \multicolumn{2}{|c|}{ Total return (Rs per ha) } & \multicolumn{2}{|c|}{ Input cost (Rs per ha) } & \multicolumn{2}{|c|}{ Net return (Rs per ha) } & \multirow{2}{*}{\begin{tabular}{|c|} 
Additional \\
return (Rs \\
per ha) \\
CFLD
\end{tabular}} & \multicolumn{2}{|c|}{ B:C ratio } \\
\hline & \begin{tabular}{|l|} 
Recommended \\
Practice (RP)
\end{tabular} & $\begin{array}{l}\text { Farmer's } \\
\text { Practice } \\
\text { (FP) }\end{array}$ & $\begin{array}{c}\text { Recommended } \\
\text { Practice (RP) }\end{array}$ & $\begin{array}{l}\text { Farmer's } \\
\text { Practice } \\
\text { (FP) }\end{array}$ & $\begin{array}{c}\text { Recommended } \\
\text { Practice (RP) }\end{array}$ & $\begin{array}{c}\text { Farmer's } \\
\text { Practice } \\
\text { (FP) }\end{array}$ & & $\begin{array}{l}\text { Recommended } \\
\text { Practice (RP) }\end{array}$ & $\begin{array}{c}\text { Farmer's Practice } \\
\text { (FP) }\end{array}$ \\
\hline 2016-17 & 43,845 & 29,369 & 21,500 & 19,000 & 22,345 & 10,369 & & 2.03 & 1.54 \\
\hline $2017-18$ &, 500 & 500 & 500 & 500 & 25,000 & 13,000 & 000 & 2. & 1.66 \\
\hline $2018-19$ & 51,840 & 35,262 & 24,000 & 20,000 & 27,840 & 15,262 & 16,578 & 2.16 & 1.76 \\
\hline $2019-20$ & 51,460 & 34,830 & 25,000 & 21,000 & 26,460 & 13,830 & 16,630 & 2.05 & 1.65 \\
\hline Average & $48,661.2$ & $32,990.25$ & 23,250 & 19,875 & $25,411.25$ & $13,115.25$ & 15,671 & 2.08 & 1.65 \\
\hline
\end{tabular}

Note: Price of black gram @ Rs.4625.00 q $\mathrm{q}^{-1}$ in 2016-17, Rs.5000.00 $\mathrm{q}^{-1}$ in 2017-18, Rs.5400.00 q $\mathrm{q}^{-1}$ in 2018-19 and Rs.5800.00 q $\mathrm{q}^{-1}$ in $2019-20$

\section{Conclusion}

The cluster frontline line demonstrations (CFLDs) conducted by KVK had enhanced the yield of black gram vertically and ensured rapid spread of recommended technologies of black gram production horizontally by implementation of various extension activities like training programmes, field days, exposure visits etc. organised under CFLD programmes in farmer's field. The CFLDs made a positive impact on yield of 
black gram by $47.52 \%$. It was observed that the potential yield of black gram variety PU31 can be achieved by imparting scientific knowledge to the farmers, providing the quality need-based inputs and their proper utilization. Therefore, it is suggested that policy maker may provide adequate financial support to frontline extension system for organising CFLD under the close supervision of agricultural scientists and extension professionals. This strategy may help to increase the pulse crop productivity at micro, meso and macro level.

\section{References}

1. Annonymous. Agricultural statistics at a glance, DAC Government of India. 2011, 118.

2. Yadav DB, Kamboj BK, Garg RB. Increasing the productivity and profitability of sunflower through frontline demonstrations in irrigated agro-ecosystem of eastern. Haryana. J Agron. 2004; 20:33-35.

3. Samui SK, Maitra S, Roy DK, Mandal AK, Saha D. Evaluation of frontline demonstration on groundnut. J Indian Soc. Coastal Agri. Res. 2000; 18(2):180-183.

4. Hiremath SM, Nagaraju MV, Shasidhar KK. Impact of frontline demonstration on onion productivity in farmer's field. Paper Presented In: National Sem. Appropriate Extn. Strat manag Rural Resource, Univ. Agric. Sci., Dharwad, 2007, 100.

5. Mishra DK, Paliwal DK, Tailor RS, Deshwal AK. Impact of frontline demonstrations on yield enhancement of potato. Indian Res. J Ext. Edu. 2009; 9(3):26-28.

6. Kumar A, Kumar R, Yadav VPS, Kumar R. Impact assessment of frontline demonstration of bajra in Haryana state. Indian Re. J Ext. Edu. 2010; 10(1):105-108.

7. Dhaka BL, Poonia MK, Meena BS, Bairwa RK. Yield and economic viability of coriander under frontline demonstrations in Bundi district of Rajasthan. J Hortl. Sci. 2015; 10(2):226-228.

8. Katare S, Pandey SK, Mustaafa M. Yield gap analysis of rapeseed-mustard through frontline demonstrations. Agric. Update. 2011; 6:5-7.

9. Meena BL, Meena RP, Meena RH, Balai CM. Yield gap analysis of rapeseed-mustard through frontline demonstrations in agroclimatic zone IV of Rajasthan. J Oilseed Brassica. 2012; 3(1):51-55.

10. Bairwa RK, Verma SR, Chayal K, Meena NL. Popularization of improved black gram production technology through frontline demonstration in humid southern plain of Rajasthan. Indian Journal of Extension Education and R D. 2013; 21:97-101.

11. Gurumukhi DR, Mishra S. Sorghum frontline demonstration- A success story. Agriculture Extension Review. 2003; 15(4):22-23.

12. Hiremath SM, Nagaraju MV. Evaluation of frontline demonstrations on the yield of chilli, Karnataka J. Agric. Sci. 2010; 23(2):341-342.

13. Singh SP, Paikra KK, Patel, Chanchala Rani. Performance of cluster frontline demonstration on productivity and profitability of Black gram (Vigna mungo) in Raigarh District of Chhattisgarh, India. Int. J Curr. Microbial. App. Sci. 2018; 7(06):1325-1330.

14. Jayalakshmi Mitnala G, Prasad Babu, Ragavendra Chowdary K, Vijayabhinandana B, Subba Rao M. Impact of Cluster Frontline Demonstrations (CFLDs) on Pulse Production, Productivity, Profitability and Transfer of Technologies in Kurnool District of Andhra Pradesh,
India. Int. J. Curr. Microbial. App. Sci. 2018; 7(12):937947

15. Saikia N, Deb Nath K, Chowdhury P. Impact of cluster frontline demonstrations on popularization of blackgram var. PU 31 in Cachar district of Barak Valley region of Assam. Journal of Pharmacognosy and Phytochemistry. 2018; 7(4):940-942. 